Eur. J. Clin. Chem. Clin. Biochem.

Vol. 30, 1992, pp. $847-850$

(C) 1992 Walter de Gruyter \& Co.

Berlin $\cdot$ New York

\title{
Serum Lipids and Apolipoprotein Concentrations and Plasma Fibronectin Concentrations in Renal Transplant Patients
}

\author{
By Ayşegül Telci, Nihal Salmayenli, Ali Emin Aydın, Sümer Yamaner, Ahmet Sivas and Uluğ Eldegez \\ Klinik Biokimya Merkez Laboratuvarı, İstanbul Tıp Fakültesi, İstanbul Üniversitesi, İstanbul, Türkiye
}

(Received February 28/June 10/July 14, 1992)

Summary: In those cases where hypertriglyceridaemia was present before renal transplantation, it persisted after transplantation, and hypercholesterolaemia also developed. We studied serum lipid, lipoprotein, and apolipoprotein concentrations and plasma fibronectin concentrations in 57 renal transplantation patients and 29 healthy controls. We concluded that atherosclerosis in renal transplantation patients might be related to alterations in the constitutions of lipoproteins and apolipoproteins, but fibronectin synthesized by vascular endothelial cells seemed not to be associated with the atherosclerotic process.

\section{Introduction}

Cardiovascular disturbances are often observed in chronic renal insufficiency, and coronary heart disease is one of the most common causes of death in patients with chronic renal failure $(1,2)$. In those cases where atherosclerosis was present before renal transplantation, it persisted after transplantation (3). In these patients, dyslipoproteinaemia is common $(2,4,5)$. In addition, hypertension, hyperuricaemia, alterations in carbohydrate metabolism, and secondary hpyerparathyroidism are contributory factors $(2,6)$. In chronic renal failure, increased serum triacylglycerol concentrations, decreased serum high density lipoprotein (HDL) cholesterol concentrations, and normal or slightly elevated plasma cholesterol concentrations are observed $(2,6,7)$. In those cases where hypertriglyceridaemia is present before renal transplantation, it persists after transplantation, and hypercholesterolaemia also develops (8). During the last 10 years, more studies have been reported on the apoproteins of the lipoproteins. Lipoprotein abnormalities are common in renal transplantation patients, but little attention has been paid to the corresponding apolipoproteins.

In this study, we compared the serum lipoprotein and apolipoprotein concentrations of renal transplantation patients with those of the controls. In addition, we investigated the possible relation of these with fibronectin, a plasma glycoprotein which had been shown to be decreased in uraemic patients (9).

\section{Materials and Methods}

The study group was made up of 57 renal transplantation patients ( 41 males and 16 females, mean age: $40.5 \pm 13.8$ years; mean time after transplantation $28.6 \pm 12.9$ months) and the control group was made up of 29 healthy volunteers (13 males and 16 females, mean age: $30.0 \pm 6.8$ years). Body mass indices were $20.1 \pm 2.9 \mathrm{~kg} / \mathrm{m}^{2}$ for the study group and $21.9 \pm 2.4$ $\mathrm{kg} / \mathrm{m}^{2}$ for the control group. The creatinine clearance of the study group was $56.5 \pm 18.4 \mathrm{ml} / \mathrm{min}$, and that of the control group was $115.5 \pm 12.6 \mathrm{ml} / \mathrm{min}$. For immunosuppression $0.5-$ $1.5 \mathrm{mg} / \mathrm{kg} \cdot \mathrm{d}$ azathioprine was administered on the first, third, eighth and fifteenth day after transplantation; prednisolone was given in doses of $100 \mathrm{mg}, 50 \mathrm{mg}, 30 \mathrm{mg}$ and $20 \mathrm{mg}$ on the first, third, eighth and fifteenth day, respectively. Appropriate doses of cyclosporin A were administered to maintain a plasma concentration of $100-200 \mu \mathrm{g} / \mathrm{l}$. All analyses were performed on blood samples taken from the ante-bracheal vein after a 12hour fast. Serum was separated immediately and kept at $-38^{\circ} \mathrm{C}$ until analysis. Fibronectin is lost during coagulation, so that fibronectin analysis in serum is less valuable than in plasma. Citrated plasma was used for fibronectin analysis. Serum total cholesterol and triacylglycerol concentrations were determined enzymatically on an automated Technicon RA-XT system. HDL cholesterol was determined in the supernatant after precipitation with phosphotungstate and $\mathrm{MgCl}_{2}$. Low density lipoprotein (LDL) cholesterol and very low density (VLDL) cholesterol were calculated by the Friedewald formula. 
Radial immunodiffusion plates were used for the determination of apolipoproteins A, A-I, B and fibronectin (Behringwerke AG, Marburg, Germany). Apolipoprotein C-II, C-III, E determinations were performed by single radial immunodiffusion (Daiichi Pharmaceutical Co., Tokyo, Japan). Student's t-test was used for the statistical analyses.

\section{Results}

Results are shown in table 1. Serum total cholesterol and triacylglycerol concentrations were increased in renal transplantation patients compared with those of the controls, and the difference between the two groups was statistically significant $(p<0.001)$. Apolipoprotein A concentrations, and apolipoprotein A/ apolipoprotein $B$ ratio were significantly increased in the transplantation group compared with those of the

Tab. 1. Serum lipid and apolipoprotein concentrations in renal transplant patients and control subjects (mean $\pm S D$ )

\begin{tabular}{lll}
\hline & $\begin{array}{l}\text { Trans- } \\
\text { plantation } \\
(\mathrm{n}=57)\end{array}$ & Control \\
& $2.32 \pm 0.49^{\mathrm{a}}$ & $1.76 \pm 0.29^{\mathrm{d}}$ \\
\hline $\begin{array}{l}\text { Cholesterol } \\
\text { (g/l) }\end{array}$ & $0.45 \pm 0.11$ & $0.47 \pm 0.12$ \\
$\begin{array}{l}\text { HDL cholesterol } \\
\text { (g/l) }\end{array}$ & $1.76 \pm 0.89^{\mathrm{a}}$ & $0.92 \pm 0.33$ \\
$\begin{array}{l}\text { Triacylglycerols } \\
\text { (g/l) }\end{array}$ & $3.61 \pm 0.82^{\mathrm{a}}$ & $2.32 \pm 0.62$ \\
$\begin{array}{l}\text { Apolipoprotein A } \\
\text { (g/l) }\end{array}$ & $2.48 \pm 0.66$ & $2.26 \pm 0.57$ \\
$\begin{array}{l}\text { Apolipoprotein A-I } \\
(\mathrm{g} / \mathrm{l})\end{array}$ & $1.71 \pm 0.45^{\mathrm{a}}$ & $1.32 \pm 0.31$ \\
$\begin{array}{l}\text { Apolipoprotein B } \\
\text { (g/l) }\end{array}$ & $2.21 \pm 0.64^{\mathrm{b}}$ & $1.76 \pm 0.55$ \\
$\begin{array}{l}\text { Apolipoprotein A/ } \\
\text { Apolipoprotein B }\end{array}$ & $1.53 \pm 0.55^{\mathrm{c}}$ & $1.84 \pm 0.72$ \\
$\begin{array}{l}\text { Apolipoprotein A-I/ } \\
\text { Apolipoprotein B }\end{array}$ & $0.07 \pm 0.03^{\mathrm{a}}$ & $0.04 \pm 0.02$ \\
$\begin{array}{l}\text { Apolipoprotein C-II } \\
\text { (g/l) }\end{array}$ & $0.06 \pm 0.02^{\mathrm{a}}$ & $0.04 \pm 0.01$ \\
$\begin{array}{l}\text { Apolipoprotein C-III } \\
\text { (g/l) }\end{array}$ & $0.23 \pm 0.09^{\mathrm{a}}$ & $0.11 \pm 0.03$ \\
$\begin{array}{l}\text { Apolipoprotein C-II/ } \\
\text { Apolipoprotein C-III }\end{array}$ & $0.27 \pm 0.07^{\mathrm{a}}$ & $0.39 \pm 0.08$ \\
$\begin{array}{l}\text { Apolipoprotein E } \\
\text { (g/l) }\end{array}$ & $0.33 \pm 0.09$ & \\
$\begin{array}{l}\text { Fibronectin } \\
\text { (g/l) }\end{array}$ & & \\
\hline & & \\
\hline
\end{tabular}

a $<0.001$

$0.001<{ }^{\mathrm{b}}<0.01$

$0.02<^{\mathrm{c}}<0.05$

d In a study performed by $A$. Azezli et al. the average of the serum total cholesterol concentrations of healthy Turkish subjects was found to be $1.65 \pm 0.03 \mathrm{~g} / \mathrm{l}$. The study contained 10625 subjects and was reported in the XV. National Congress of Endocrinology in Izmir in 1991 (31). control group ( $\mathrm{p}<0.001)$. Apolipoprotein C-II and apolipoprotein $\mathrm{E}$ concentrations were increased, and the apolipoprotein C-II/apolipoprotein C-III ratio was significantly decreased in the renal transplantation group ( $p<0.001)$. There was no difference in fibronectin concentrations between the two groups. The correlation of fibronectin with lipids and lipoproteins was investigated in both groups and a moderate correlation was found between fibronectin and apolipoprotein C-II in the control group.

\section{Discussion}

Cardiovascular disturbances are frequent in chronic renal insufficiency $(1,3)$. It has been reported that if atherosclerosis has begun before transplantation, it then continues to develop after renal transplantation (3). Hypertriglyceridaemia is present in the majority of patients who are uraemic or on maintenance dialysis; it persists after transplantation, together with the development of hypercholesterolaemia (8). Lipoprotein disturbances are common both in chronic renal insufficiency and in renal transplant patients, but few studies have been reported on apolipoproteins in transplant patients. Total cholesterol, HDL cholesterol and apolipoprotein A have been reported to be high in patients with renal transplants $(10,11)$. Some investigators have reported that HDL cholesterol concentrations were normal or decreased $(12,13)$. We found that serum total cholesterol and apolipoprotein A concentrations were increased in renal transplant patients compared with those of the control group. We found no difference in HDL cholesterol concentrations between the two groups.

Apolipoprotein A and apolipoprotein A-I are the main protein components of HDL $(14,15)$. We found that there was no difference in serum apolipoprotein A-I concentrations between transplant patients and the control group. The present study shows a decrease in the serum apolipoprotein A-I/apolipoprotein B ratio and an increase in serum apolipoprotein A concentrations. Thus, hypercholesterolaemia and premature cardiovascular disease can be explained by the changes in the composition of apolipoprotein A and apolipoprotein A-I, which are major apolipoproteins of HDL.

Hyperlipidaemia, which is common in dialysis patients, often persists after renal transplantation in spite of a return to normal renal function. Corticosteroid immunosuppression has been suggested as a cause of these lipid abnormalities. The importance of hyperlipidaemia after transplantation is that it is the major cause of death after renal transplantation (16). 
In vitro studies have also shown that corticosteroids disturb the uptake of normal LDL cholesterol particles by the receptors (17). Thus, LDL cholesterol metabolism in renal transplant patients is different from that in normal subjects. Immunosuppression regimens using low-dose prednisolone do not cause hyperlipidaemia. In contrast, immunosuppression with cyclosporin, either alone or with prednisolone, gives rise to a significant increase in LDL cholesterol in the first three months after transplantation. The mechanism of this is not known and it is not due to impairment of renal function by cyclosporin, but it may be related to the transport of cyclosporin by plasma lipoproteins. If the patient is maintained on long-term cyclosporin immunosuppression, hypercholesterolaemia may be a potential risk factor for cardiovascular morbidity (16).

In our patients, prednisolone and cyclosporin together with azathioprine were used for immunosuppression after renal transplantation.

In the present study, serum total cholesterol concentrations were increased, and apolipoprotein A-I/apolipoprotein $B$ ratios were decreased in renal transplant patients, compared with the controls. Thus, LDL cholesterol concentrations were also increased. These results are in agreement with studies indicating that cyclosporin, either alone or with prednisolone, causes a significant increase in LDL cholesterol after transplantation.

In the light of these results, we think that LDL cholesterol metabolism in renal transplant patients is different from that in normal subjects, and that hypercholesterolaemia is a possible risk factor for cardiovascular disease in these patients.

Triacylglycerol concentrations were significantly increased in renal transplant patients compared with those of the controls. Hypertriglyceridaemia, which has started during the predialytic phase accelerates during dialysis and continues after transplantation $(10,18,19)$. Apolipoprotein C-II is the activator of lipoprotein lipase ${ }^{1}$ ), an enzyme that regulates triacylglycerol metabolism, and apolipoprotein C-III is the inhibitor of the same enzyme $(20,21)$. The apolipoprotein C-II/apolipoprotein C-III ratio is a marker of the regulation of lipoprotein lipase activity (2). Depressed activities of the lipoprotein lipase and hepatic lipase result in reduced catabolism of triacylglycerolrich lipoproteins and thus a delay in the clearance of

\footnotetext{
${ }^{1)}$ Enzyme

Lipoprotein lipase (EC 3.1.1.34)
}

the remnants, so that the conversation of intermediate density lipoprotein (IDL) - to low density lipoprotein (LDL) is impaired $(2,10,22)$. A variety of studies have indicated that both impaired removal and increased production of triacylglycerol-rich lipoproteins contribute to the hypertriglyceridaemia of chronic renal failure. More recent studies suggest that a defective removal of triacylglycerol-rich lipoproteins in such patients may be a more significant contributory factor than increased production (23). This view is supported by studies demonstrating reduced plasma postheparin lipolytic activity, and decreased clearance of triacylglycerols in chronic renal failure $(23,24)$. This may be the cause of hypertriglyceridaemia in our patients.

Apolipoprotein $\mathrm{E}$ is approximately equally distributed between VLDL and HDL in normal plasma. It has been shown that apolipoprotein $\mathrm{E}$ plays a role in the pathogenesis of atherosclerosis $(25,26)$. Modulation of smooth muscle cell proliferation and migration is of particular importance in arterial wall pathophysiology (27). Heparin and heparin-like glycosaminoglycans, added exogenously or produced by cells within the artery wall, are potent inhibitors of smooth muscle cell proliferation and motility (26). Apolipoprotein $\mathrm{E}$ could play a role in smooth muscle cell biology because of its ability to bind to heparin and heparin-like glycosaminoglycans that are present in the matrix of the arterial wall. The formation of apolipoprotein E-heparin like complexes could modify the interaction of smooth muscle cells with the matrix. Apolipoprotein E production may also participate in smooth muscle cell differentiation (26). Therefore, in our renal transplant patients, increased apolipoprotein $\mathrm{E}$ concentrations may be related to cardiovascular risk.

We also investigated plasma fibronectin concentrations in transplantation patients and found no significant difference between those of the controls. The presence of fibrinogen or fibrin antigen in atherosclerotic lesions has been confirmed by a number of investigators (28). Fibrinogen forms complexes with fibronectin and factor XIII, proteins playing a significant role in tissue repair $(29,30)$. Fibronectin is essential for the formation of granulation tissue, for chemotaxis of fibroblasts and for migration of smooth muscle cells stimulated by platelet-derived growth factor. Preliminary data indicated that fibronectin can be extracted from normal intima, from early proliferative lesions and from mural thrombi (28). Further studies are needed to determine the role of fibronectin and factor XIII (transamidase) in the pathogenesis of atherosclerotic lesions. 
These results show that atherosclerosis in renal transplantation patients is associated with alterations in lipoproteins and apolipoproteins contained in these lipoproteins. On the other hand, according to our findings, plasma fibronectin synthesized by vascular endothelial cells seems not to be associated with the atherosclerotic process. Further studies are in progress.

\section{References}

1. Brunner, F. P., Brynger, H. \& Chantler, C. (1978) Combined report on regular dialysis and transplantation in Europe, IX, 1978. Proc. Eur. Dial. Transplant Ass. 16, 3-82.

2. Cassader, M., Ruiu, G., Tagliaferro, V., Triolo, G. \& Pagano G. (1989) Lipoprotein and apoprotein levels in different types of dialysis. Int. J. Artif. Organs. 12, 433-438.

3. Lazarus, J. M., Lowrie, E. G., Hampers, C. L. \& Merril, J. P. (1975) Cardiovascular disease in uremic patients on hemodialysis. Kidney Int. 7, S167-S175.

4. Lacour, B., Roullet, J. B., Beyne, P., Kreis, H., Thevenin, M. \& Drüeke, T. (1985) Comparison of several atherogenicity indices by the analysis of serum lipoprotein composition in patients with chronic renal failure with or without haemodialysis, and in renal transplant patients. J. Clin. Chem. Clin. Biochem. 23, 805-810.

5. Feldman, H. A. \& Singer, I. (1974) Endocrinology and metabolism in uremia and dialysis: a clinical review. Medicine 54, 345-376.

6. Grützmacher, P., Marz, W., Peschke, B., Gross, W. \& Schoeppe, W. (1988) Lipoproteins and apolipoproteins during the progression of chronic renal disease. Nephron 50 , $103-111$.

7. Norbeck, H. E., Oro, L. \& Carlson, L. A. (1976) Serum lipid and lipoprotein concentrations in chronic uremia. Acta Med. Scand. 200, 487-492.

8. Allegra, V., Mengozzi, G. \& Vasile, A. (1989) Lipoprotein lipids and apoproteins in healthy renal transplant recipients. Nephron 51, 276-277.

9. Eriksen, H. O., Tranebjaerg, L., Clemmensen, I., Kjersem, H. \& Skjoldby, O. (1983) Plasma fibronectin concentration in patients with chronic renal failure and treated with haemodialysis. Scand. J. Clin. Lab. Invest. 43, 723-726.

10. Ibels, L. S., Reardon, M. F. \& Nestel, P. J. (1976) Plasma post-heparin lipolytic activity and triglyceride clearance in uremic and hemodialysis patients and renal allograft recipients. J. Lab. Clin. Med. 87, 648-658.

11. Kobayashi, N., Okubo, M., Marumo, F., Uchida, H., Endo, T. \& Nakamura, H. (1983) De Novo development of hypercholesterolemia and elevated high-density lipoprotein cholesterol: apoprotein AI ratio in patients with chronic renal failure following kidney transplantation. Nephron 35, $237-240$.

12. Ibels, L. S., Simons, L. A., King, J. O., Williams, P. F., Neale, F. C. \& Stewart, J. H. (1975) Studies on the nature and causes of hyperlipemia of uremia maintenance dialysis and renal transplantation. Q. J. Med. 44, 601-605.

13. Bagdade, J. D., Casaretto, A. \& Albers, J. (1976) Effect of chronic uremia, hemodialysis and renal transplantation on plasma lipids and lipoproteins in man. J. Lab. Clin. Med. 87, 37-48.

14. Wakabayashi, Y., Okubo, M. \& Shimada, H. (1987) Decreased VLDL apoprotein CII/apoprotein CIII ratio may be seen in both normotriglyceridemic and hypertriglyceridemic patients on chronic hemodialysis treatment. Metabolism 36, 815-820.

15. Ohta, T. \& Matsuda, I. (1985) Apolipoprotein and lipid abnormalities in uremic children on hemodialysis. Clin. Chim. Acta 147, 145-154.

16. Raine, A. E. G., Carter, R., Mann, J. I., Chapman, J. R. \& Morris, P. J. (1987) Increased plasma LDL cholesterol after renal transplantation associated with cyclosporine immunosuppression. Transplant. Proc. 19, 1820-1821.

17. Hirsch, L. J. \& Mazzone, T. (1986) Dexamethasone modulates lipoprotein metabolism in cultured human monocyte receptor activity. J. Clin. Invest. 77, 485-490.

18. Savdie, E., Gibson, J. C., Crawford, G. A., Simons, L. A. \& Mahony, J. F. (1980) Impaired plasma triglyceride clearance as a feature of both uremic and post-transplant triglyceridemia. Kidney Int. 18, 774-782.

19. Nicholls, A. J., Cumming, A. M., Catto, G. R. D., Edward, N. \& Engest, J. (1981) Lipid relationships in dialysis and renal transplant patients. Q. J. Int. Med. 50, 149-160.

20. Nilsson-Ehle, P., Garfinkel, A. S. \& Schotz, M. C. (1980) Lipolytic enzyme and plasma lipoprotein metabolism. Ann. Rev. Biochem. 49, 667-693.

21. Havel, R. J., Shore, V. G., Shore, B. \& Bier, D. M. (1970) Role of specific glycoproteins of human serum lipoproteins in the activation of lipoprotein lipase. Circ. Res. 27, 595600 .

22. Cattran, D. C., Fenton, S. S. A., Wilson, D. R. \& Steiner, G. (1976) Defective triglyceride removal in lipemia associated with peritoneal dialysis and hemodialysis. Ann. Intern. Med. 85, 29-33.

23. Alsayed, N. \& Rebourcet, R. (1991) Abnormal concentrations of CII, CIII, and E apolipoproteins among apolipoprotein B-containing, B-free, and AI-containing lipoprotein particles in hemodialysis patients. Clin. Chem. 37, 387393.

24. Chan, M. K., Vorghese, Z. \& Persaud, J. N. (1983) Hyperlipidemias in patients on maintenance hemo- and peritoneal dialysis: the relative pathogenic role of triglyceride production and triglyceride removal. Clin. Nephrol. 17, $183-190$.

25. Rall, S. C., Weisgraber, K. H. \& Mahley, R. W. (1982) Human apolipoprotein E: The complete amino acid sequence. J. Biol. Chem. 257, 4171-4178.

26. Mahley, R. W. (1988) Apolipoprotein E: Cholesterol transport protein with expanding role in cell biology. Science $240,622-630$.

27. Ross, R. (1986) The pathogenesis of atherosclerosis - an update. N. Engl. J. Med. 314, 488-500.

28. Niewiarowski, S.\& Rao, K. (1983) Contribution of thrombogenic factors to the pathogenesis of atherosclerosis. Prog. Card. Dis. 26, 197-222.

29. Mosesson, M. W. \& Amrani, S. L. (1980) The structure and biologic activities of plasma fibronectin. Blood 56, $145-158$.

30. Greenberg, C. S. \& Shuman, M. A. (1982) The zymogen forms of blood coagulation factor XIII bind specifically to fibrinogen. J. Biol. Chem. 257, 6096-6101.

31. Azezli, A., Taşçığlu, C., Orhan, Y., Molvalılar, S., Sencer, E. (1991) Türk Toplumunda Sağlıklı Kişilerde Kolesterol, Trigliserid ve Lipoprotein Fraksiyonları Değerleri XV. Ulusal Endokrinoloji Kongresi, 1 - 4 Ekim 1991, Konak-İzmir (Cholesterol, Triacylglycerol and Liproprotein Fractions of Healthy Subjects in Turkish Population, XV. National Congress of Endocrinology, October 1-4th, 1991 Konak-İzmir).

Prof. Dr. Ahmet Sivas

Department of Clinical Biochemistry

İstanbul Faculty of Medicine

Çapa

İstanbul

Turkey

Eur. J. Clin. Chem. Clin. Biochem. / Vol. 30, 1992 / No. 12 